\title{
USER SPECIFICATIONS FOR PRESSURE VESSELS AND TECHNICAL INTEGRITY
}

\author{
K.S. Johnston ${ }^{1}$ and J.E. Amadi-Echendu ${ }^{2}$ \\ ${ }^{1,2}$ Graduate School of Technology Management \\ University of Pretoria, South Africa \\ ${ }^{1}$ Keith.johnston@sasol.com, ${ }^{2}$ joe.amadi-echendu@up.ac.za
}

\begin{abstract}
Specifications translated from user requirements are prescribed in an attempt to capture and incorporate best practices with regards to the design, fabrication, testing, and operation of pressure vessels. The question as to whether these requirements affect the technical integrity of pressure vessels is often a subjective matter. This paper examines typical user requirement specifications against technical integrity of pressure vessels.
\end{abstract}

The paper draws on a survey of a convenience sample of practising engineers in a diversified petrochemical company. When compared with failures on selected pressure vessels recorded by Phillips and Warwick, the respondent feedback confirms the user specifications that have the highest impact on technical integrity.

\section{OPSOMMING}

Gebruikersbehoeftes word saamgevat in spesifikasies wat lei tot goeie praktyk vir ontwerp, vervaarding, toetsing en bedryf van drukvate. Subjektiwiteit van die gebruikersbehoeftes mag soms die tegniese integriteit van 'n drukvat beinvloed.

Die navorsing maak by wyse van monsterneming gebruik van die kennis van ingenieurs wat werk in ' $n$ gediversifiseerde petrochemiese bedryf. Die terugvoering bevestig dat bogenoemde spesifikasies inderdaad die grootste invloed het op tegniese integriteit.

${ }^{1}$ The author was enrolled for an M Eng (Technology Management) in the Department of Engineering and Technology Management, University of Pretoria. 


\section{INTRODUCTION}

Over time, the engineering profession has developed rules and regulations for the safe design, construction, and testing of equipment. The petrochemical industry, in particular, has documented and standardized these rules in the form of codes and standards. The American Society of Mechanical Engineering (ASME) and the British Standards (BS) are the most widely referenced. [1]

Codes and standards are developed to provide for safe design, construction, and testing, and because of this, such codes have formed legislative requirements dealing with pressurized equipment. In most countries legal compliance with respect to pressurized equipment implies that the equipment will need to conform to the requirements of a recognized code or standard. [1]

Specifications in the form of user requirements are developed by the user in an attempt to encapsulate best practices in the design, fabrication and testing of equipment. These specifications cover safety issues and user operational requirements pertaining to the specific use of vessels and columns. A large part of user requirements for vessels and columns focuses on constructability and maintainability to establish a given level of technical integrity - that is, an assurance that, under given conditions, there is no foreseeable risk of failure that will endanger safety or the environment, or adversely affect the business value associated with operating the vessel. [2]

Failures of pressure vessels may be broadly categorised according to the survey of Phillips and Warwick cited in [3] and summarised in Table 1, showing that in-service related failures occur more frequently than during vessel construction.

\begin{tabular}{|c|c|c|c|}
\hline & \multirow[t]{2}{*}{ Sample Size } & \multicolumn{2}{|c|}{$\begin{array}{c}\text { Failure rate } \\
\text { (Failures/year) }\end{array}$} \\
\hline & & $\begin{array}{c}\text { Potentially } \\
\text { Dangerous }\end{array}$ & Catastrophic \\
\hline $\begin{array}{l}\text { Failure in } \\
\text { construction }\end{array}$ & $\begin{array}{l}12,700 \\
\text { vessels }\end{array}$ & $5.5 \times 10^{-4}$ & $2.3 \times 10^{-4}$ \\
\hline Failure in service & $\begin{array}{c}100,300 \\
\text { vessel-yrs }\end{array}$ & $1.25 \times 10^{-3}$ & $0.7 \times 10^{-4}$ \\
\hline
\end{tabular}

Table 1: Pressure vessel failure categories [3]

Of pressure vessel failures, $89.3 \%$ may be attributed to cracks that are mostly caused by a $35.6 \%$ fatigue rate, as shown in Table 2 . 


\begin{tabular}{|lcc|}
\hline Causes of failure: & 118 & 89.3 \\
\hline Cracks & 8 & 6.1 \\
\hline Mal-operation & 3 & 2.3 \\
\hline Pre-existing from manufacture & 2 & 1.5 \\
\hline Corrosion & 1 & 0.8 \\
\hline Creep & 132 & 100 \\
\hline Causes of Cracks: & & \\
\hline Fatigue & 47 & 35.6 \\
\hline Corrosion & 24 & 18.2 \\
\hline Pre-existing from manufacture & 10 & 7.6 \\
\hline Miscellaneous & 2 & 1.5 \\
\hline Not ascertained & 35 & 26.5 \\
\hline & 118 & 89.4 \\
\hline Method of detection: & & \\
\hline Visual examination & 75 & 56.9 \\
\hline Leakage & 38 & 28.8 \\
\hline Non-destructive testing & 10 & 7.5 \\
\hline Hydraulic tests & 2 & 1.5 \\
\hline Hydraulic tests & 7 & 5.3 \\
\hline Catastrophic failure & 132 & 100 \\
\hline
\end{tabular}

Table 2: Causes of pressure vessel failure [3]

\section{RESEARCH}

\subsection{User requirements}

The user's requirements, when translated into technical specifications, assist during the acquisition of new process vessels. The requirements specified by the user are over and above design codes and standards used to design and construct pressure vessels. A user may choose to specify any amount of detail to optimize the vessel design and fabrication to fit a specific process environment, based on experience or best practice.

The requirements address technical issues ranging from Mechanical Flow Diagram (MFD) vessel optimization through to detailed design and fabrication issues. Requirements addressing the integrity of pressure vessels are not always immediately evident when reading a specification; so one aspect of this study was to identify user requirements that significantly impact on the technical integrity of pressure vessels. 


\subsection{Survey}

Once the requirements addressing technical integrity had been extracted from the specifications, it was necessary to determine which of the requirements were perceived to have the highest impact on the technical integrity of a pressure vessel.

A group of 42 engineers working in the engineering division of a diversified petrochemical company were given a questionnaire based on the user requirements they generate. They were asked to rate the requirements, based on the level of impact they feel the requirements have on the technical integrity of pressure vessels.

The following list of technical specifications for pressure vessels, as adopted by the engineers, formed the basis of a survey questionnaire.

Pressure vessel specifications

1. Mandatory Requirements for Boilers, Pressure Vessels, and Portable Gas
2. $\quad$ Pressure Vessels Categories 1,2 and 3
3. Pressure Vessels - Supplement for Carbon and Low Alloy Steels
4. Pressure Vessels - Supplement for Austenitic and High Alloy Steels
5. Pressure Vessels - Supplement for Alloy Clad and Alloy Lined Steel
6. Pressure Vessels - Supplement for Slender Vertical Vessels
7. Pressure Vessels - Supplement for Severe Services
8. Pressure Vessels Category 4
9. Vessel Trays - General
10. Welding of Pressure Vessels : Categories 1,2 and 3
11. Pressure Equipment
12. Heat Treatment
13. Selection of Materials for Low Temperature Service

14. Mechanical Engineering Requirements - Specification Clarifications and

\section{Table 3: Technical Specifications for Pressure Vessels}

The survey was administered to a select group of engineers who develop and maintain the user requirements for process vessels for the company. The requirements address a wide range of technical issues, so the questions were divided into three sections: 

i) design and constructability requirements
ii) quality and material requirements
iii) welding and fabrication requirements

The respondents were then asked to rank these requirements with respect to the effect on the technical integrity of a process vessel.

The profile of the respondents ranged from junior engineers who had just joined the company, to chief engineers who had been with the company for over 20 years. For the company this meant that four different grades of engineers had responded to the questionnaire and given their rating for the impact a requirement would have on technical integrity. Because of this the ratings were preferentially weighted towards the higher job levels.

\subsection{Actual defects}

Historical data for 78 process columns in a refinery was analyzed to determine the types of defects that occur in practice. Data was gathered from routine inspection reports for the process columns, dating back to the fabrication of the vessels in about 1977. Metallurgical data reports were sourced as a second basis for recording material defects for the vessels.

\subsection{Results}

It can be seen that with respect to design and constructability, the requirements that the respondents ranked highest address the design of weldments. The top ranking requirement is the use of integral reinforcement (as opposed to compensation pad reinforcement) for nozzle openings. This reduces the amount of welding on the vessel. The requirement that addresses the weld design of the head to skirt attachment welds for process vessels classified as being slender (i.e. a length over diameter ratio of greater than 10) was ranked second highest. Here, attention is given to the weld to ensure that fatigue cracking does not occur.

The third highest ranking requirement addresses the connection detail of nozzles where cyclic loading occurs. In this case the nozzle to shell attachment weld is changed from a corner weld to a full penetration butt weld, where the root can be inspected. This takes the weld away from the area that would see the highest stresses during nozzle loading, and so reduces the risk of crack generation in the weldment of the corner weld. 
Respondent ranking of grouped specifications

Weighted average as a \% of total

Design and constructability:

\begin{tabular}{lc}
\hline $\begin{array}{l}\text { Integral reinforcement on high pressure and high } \\
\text { temperature pressure vessels }\end{array}$ & 7.67 \\
\hline $\begin{array}{l}\text { Skirt to shell weld on tall vessels to be fatigue resistant } \\
\text { Cyclic loaded vessels to have lip type forgings }\end{array}$ & 7.32 \\
$\begin{array}{l}\text { Full penetration welding of nozzles 3" and larger for } \\
\text { nozzle to shell weld }\end{array}$ & 7.27 \\
Material selection and quality: & 7.21 \\
\hline Stress relieving of formed head & 7.75 \\
\hline $\begin{array}{l}\text { 0.25\% max carbon content for carbon steels } \\
\text { No dissimilar metals welds in process service }\end{array}$ & 7.57 \\
\hline $\begin{array}{l}\text { Re-certification of hot formed parts } \\
\text { Welding: }\end{array}$ & 7.5 \\
\hline $\begin{array}{l}\text { Fatigue finish of welds in cyclic service } \\
\text { PWHT for welds in amine service }\end{array}$ & 7.49 \\
\hline $\begin{array}{l}\text { Corrosive service austenitic stainless steel to be of low } \\
\text { carbon or stabilized grade }\end{array}$ & 14.89 \\
$\begin{array}{l}\text { Load bearing attachment weld to be full penetration } \\
\text { welded to vessel }\end{array}$ & 14.12 \\
\hline
\end{tabular}

Table 4: Respondent ranking of grouped specifications

The fourth highest ranking requirement addresses the nozzle to shell attachment weld for all services. The requirement states that all nozzles 3 inches and larger should be attached to the vessel using a full penetration butt weld. The change from a fillet weld to a butt weld is to remove the uncertainty of the stress raiser that might occur at the root of the fillet weld, and that could cause a crack to propagate.

In the section on material selection and quality, the requirement ranked the highest addresses the stress relieving of formed heads. Residual stresses induced during the forming process need to be relieved, and stress relieving the head ensures that residual stresses are relieved and do not result in crack formation in the heads. The second highest requirement in this section addresses the maximum carbon content for carbon steels. The carbon content of steels affects the weldability of the steel, making the weldment harder and more brittle. The maximum limit on carbon content is therefore used to ensure that brittle zones that are prone to cracking do not form. The requirement that ranked third highest addresses the welding of dissimilar metals. This is prohibited for welds in contact with the process, since a galvanic corrosion could result. The re-certification of hot formed parts was the fourth highest ranked requirement, and addresses the issue of ensuring that hot formed parts are restored to original material properties using certification to record the process. 
In the section on welding, the highest ranked requirement addresses the finish of welds in cyclic service. The welds are to be fatigue dressed - i.e. the weld is to be ground to a smooth even transition, and no stress raisers are allowed. This requirement ensures that no area of the weld is prone to cracking. The second highest requirement addresses the Post Weld Heat Treatment (PWHT) of welds in amine service. Here again, the weld is relieved of residual stresses to ensure that it is not prone to cracking. The third requirement addresses the use of stainless steels in corrosive services. The requirement ensures that low carbon content or stabilized stainless steels are used for these applications. The focus is on reducing the possibility of carbon rich zones forming at welding sites, and therefore it reduces these areas' susceptibility to preferential corrosion. The fourth highest requirement ensures that load bearing attachment welds to the shell be full penetration. This ensures that fillet welds are not used, as they can crack into the shell material if a load is applied.

The results based on historical data presented the following results in the context of defects over the life of the process columns.

\begin{tabular}{|lcc|}
\hline Total number of cases & $\begin{array}{c}\text { No. of } \\
\text { cases }\end{array}$ & $\begin{array}{c}\text { \% of total } \\
\text { cases }\end{array}$ \\
\hline \begin{tabular}{|c|c|} 
Causes of failures: \\
Corrosion
\end{tabular} & & \\
\hline Cracks & 71 & 85.5 \\
\hline De-lamination of thermal coating & 8 & 9.6 \\
\hline Causes of corrosion: & 4 & 4.8 \\
\hline Incorrect material selection & 70 & 98.6 \\
\hline Galvanic corrosion & 1 & 18.2 \\
\hline
\end{tabular}

Table 5: Defects over the lifetime of process columns

It is clear from the data presented in Table 5 that of the seventy eight process columns analysed, the majority of defects experienced over the life of the vessel, at $85.5 \%$, of the 83 cases is directly related to corrosion.

When the cause of corrosion was investigated, it was found that $98.6 \%$ of the cases were attributable to incorrect material selection for the process application. 


\section{ANALYSIS}

\subsection{Comparisons}

When the results from the respondents are compared with the Phillips and Warwick data, it can immediately be seen that ten of the twelve requirements rated by respondents as having the greatest impact on vessel integrity relate to preventing crack formation in the vessel material. When the Phillips and Warwick data is considered, we see that $89.3 \%$ of the cases causing failures result from cracks. On further investigation of the reason for these cracks, it is observed that fatigue constitutes the largest cause (35.6\% of the total number of cases). Three of the twelve SASOL specification requirements address fatigue specifically. The second highest cause for cracking in the Phillips and Warwick data is corrosion (18.2\%). When the results from the respondents are analysed, it is observed that four of the top twelve ranked SASOL requirements address cracking as a result of corrosion.

The specification requirements ranked highest in the questionnaire are similar to the requirements that the Phillips and Warwick data rates highest for failures in industry.

When the data is compared with the historical data reports and history of the vessels in the refinery investigated, it is apparent that the area regarding corrosion as a result of incorrect material selection was where most defects were experienced.

\section{SUMMARY}

It is reassuring that the requirements given a priority ranking by the respondents align with the causes for failure identified in the Phillips and Warwick research data. However, the area contributing to the majority of defects experienced was material selection, and these requirements would need to be specified in more detail.

\section{ACKNOWLEDGEMENT}

The authors wish to express appreciation to SASOL South Africa for the case studies referred to in the paper.

\section{REFERENCES}

[1] Couper, J.R., Penny, W.R., Fair and Walas S., 2005. Chemical process equipment: Selection and design. $2^{\text {nd }}$ edition, Gulf Professional Publishing, chapter 1.5.

[2] Coley Consulting 2007. What is a requirement? www.coleyconsulting.co.uk/require.htm. Accessed on 1 October 2008.

[3] Mannan, S. 2005. Lees' loss prevention in the process industries. Elsevier, chapter 12.30. 